\title{
PENGEMBANGAN KNOWLEDGE SISTEM PEMILIHAN BIBIT SAWIT MENGGUNAKAN PENDEKATAN USABILITY ENGINEERING DINAS PERKEBUNAN PROVINSI PAPUA
}

\author{
Surianti $^{1}$, Nur Ain Banyal ${ }^{2}$ \\ Dosen STMIK Umel Mandiri ${ }^{1}$ \\ Jalan Raya Abepura Kotaraja Jayapura-Papua \\ Sur-el : surianti12p@gmail.com ${ }^{1}$, nur.ain.banyal@gmail.com²
}

\begin{abstract}
One way to guarantee the development of oil palm in Indonesia is to ensure the availability of superior and quality seeds. Besides that, the development of the oil palm plantation industry so far has not been fully followed by an adequate increase in the nursery industry, even though seedlings play an important role in increasing the productivity of palm oil in general. Data collection method used is observation. Observation is a technique to go directly to the field at the Papua Provincial Plantation Office. This study uses a usability engineering approach and knowledge management system life cycle (KMSLC) method. The results of this study are in the form of a palm oil seed knowledge management system in which data sources used also include book documents, journals especially those from oil palm research centers and provide consultations with oil palm experts. Error rates in this application are very low and few. Scores from each category are above average, meaning that usability in this system is good.
\end{abstract}

Keywords: Palm Oil, KMSLC, Knowledge Management System, Usability Engineering

\begin{abstract}
Abstrak : Salah satu cara untuk menjamin pengembangan kelapa sawit di Indonesia adalah menjamin ketersediaan bibit unggul dan bermutu. Disamping itu perkembangan industri perkebunan kelapa sawit selama ini belum sepenuhnya diikuti dengan peningkatan industri perbibitan yang memadai, padahal bibit sangat memegang peranan penting dalam meningkatkan produktivitas kelapa sawit secara umum. Metode pengumpulan data yang digunakan adalah Observasi. Observasi adalah teknik terjun langsung ke lapangan pada Dinas Perkebunan Provinsi Papua. Penelitian ini menggunakan pendekatan usability engineering dan metode knowledge management system life cycle (KMSLC). Hasil dari penelitian ini berupa sistem manajemen pengetahuan bibit sawit yang mana sumber data yang digunakan pun meliputi dokumen buku, jurnal terutama yang berasal dari pusat penelitian kelapa sawit serta menyediakan konsultasi dengan pakar sawit. Error rate pada aplikasi ini sangat rendah dan sedikit. Skor dari setiap kategori berada diatas rata-rata artinya usability pada sistem ini sudah baik.
\end{abstract}

Kata kunci: kelapa sawit, KMSLC, Knowledge Management System, Usability Engineering

\section{PENDAHULUAN}

Tanaman kelapa sawit (Eleis guinensis Jack) memiliki arti penting bagi pembangunan perkebunan nasional. Pada masa orde baru, pembangunan perkebunan diarahkan dalam rangka menciptakan kesempatan kerja, meningkatkan kesejahteraan masyarakat dan sebagai sektor penghasil devisa Negara. Pemerintah pun terus mendorong pembukaan lahan baru untuk perkebunan kelapa sawit. Sampai dengan tahun 1980 luas lahan mencapai 294.560 ha. Sejak saat itu lahan perkebunan kelapa sawit Indonesia berkembang pesat terutama perkebunan dikelola oleh rakyat [1]. Salah satu cara untuk menjamin pengembangan kelapa sawit di Indonesia adalah menjamin ketersediaan bibit unggul dan bermutu. Disamping itu perkembangan industri perkebunan kelapa sawit selama ini belum 
sepenuhnya diikuti dengan peningkatan industri perbibitan yang memadai, padahal bibit sangat memegang peranan penting dalam meningkatkan produktivitas kelapa sawit secara umum [2]. Hal ini disebabkan kurangnya pengetahuan tentang arti bibit yang bermutu karena kurangnya penyebaran informasi terhadap bibit kelapa sawit terutama terhadap masyarakat petani. Penggunaan bibit kelapa sawit tidak bermutu yang pada umumnya digunakan pada perkebunan rakyat dilatarbelakangi oleh kesenjangan antara masyarakat dengan produsen bibit karena ketidaktahuan para pengguna tentang bibit unggul akibat kurangnya sosialisasi, harga bibit asalan (tidak bermutu) lebih murah dari bibit unggul, jarak antara kebun dengan sumber bibit unggul jauh dan juga kelihaian para pemasok bibit asalan (tidak bermutu) kepada para pemakai.

Dengan adanya masalah kurangnya pengetahuan para petani dalam mengelola lahan bibit terutama pada perkebunan sawit maka perlu dibangun sistem yang bisa menyimpan dan menyalurkan informasi sehingga bisa digunakan oleh petani sawit dan dapat menentukan bibit yang cocok untuk digunakan di suatu Daerah[3]. Sistem manajemen pengetahuan merupakan integrasi antara teknologi dan mekanisasi yang dibangun untuk mendukung proses manajemen pengetahuan [4]. Manajemen pengetahuan telah dipraktekkan selama bertahun-tahun, Pengetahuan telah memotivasi peneliti dalam menjawab pertanyaan-pertanyaan yang berkaitan dengan bagaimana mendefenisikan dan mengoperasionalkan gagasan manajemen pengetahuan. Knowledge adalah penggabungan antara pengalaman, nilai, informasi kontekstual, pandangan dan intuisi para pakar yang membangun lingkungan dan kerangka evaluasi dan juga gabungan pengalaman dan informasi baru[5]. Sistem manajemen pengetahuan merupakan integrasi antara teknologi dan mekanisasi yang dibangun untuk mendukung proses manajemen pengetahuan. Manajemen pengetahuan telah dipraktekkan selama bertahun-tahun dalam organisasi yang menghargai suatu pengetahuan[6]. Pengetahuan telah memotivasi peneliti dalam menjawab pertanyaan-pertanyaan yang berkaitan dengan bagaimana mendefenisikan dan mengoperasionalkan gagasan manajemen pengetahuan[7].

\section{METODOLOGI PENELITIAN}

Metode pengumpulan data yang digunakan adalah Observasi. Observasi adalah teknik terjun langsung ke lapangan pada Dinas Perkebunan Provinsi Papua. Penelitian ini menggunakan pendekatan usability engineering dan metode knowledge management system life cycle (KMSLC). Usability merupakan pengukuran karakteristik produk berdasarkan user interface dengan tingkatan baik dan lemah [8]. Usability sangat diperlukan untuk mengevaluasi sistem yang akan dirancang menggunakan pengujian usabilitas melalui kuesioner terhadap pengguna [9]. KMSLC yang digunakan merupakan adopsi dari KMSLC dari yang terdiri dari analisis, identifikasi sumber daya, identifikasi sumber pengetahuan, perancangan, verifikasi dan validasi KMS, 
implementasi $\mathrm{KM}$ sistem dan evaluasi sistem[10].

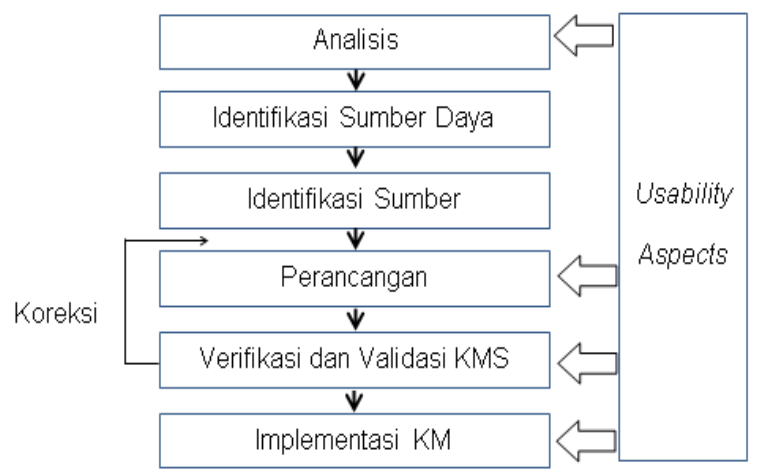

Gambar 1. Metodologi Penelitian

Metode yang digunakan dalam pembuatan sistem ini yaitu Knowledge Management System Life Cycle[10]. Tahapan pembentukan sistem manajemen pada model ini meliputi :

a. Analisis, yaitu dengan melakukan analisa infrastruktur manajemen pengetahuan yang sedang berjalan sehingga infrastruktur tersebut dapat dikembangkan dan diperbaiki sesuai dengan kebutuhan.

b. Identifikasi sumber daya, yaitu dengan melakukan identifikasi stakeholder yang kemudian dilibatkan dalam pembuatan sistem manajemen pengetahuan.

c. Identifikasi sumber pengetahuan, yaitu menangkap pengetahuan baik berupa pengetahuan tacit maupun explicit untuk kemudian didokumentasikan. Dilakukan dengan merubah buku, jurnal, prosiding menjadi cd atau file-file elektronik.

d. Perancangan, yaitu menggambarkan secara detail mengenai rancangan dari aplikasi sistem manajemenen pengetahuan yang akan dikembangkan.

e. Verifikasi dan validasi KMS, yaitu menyesuaikan pengetahuan yang terdapat pada proses perancangan.

f. Implementasi KM sistem, menerapkan pengetahuan pada sebuah sistem yang dilanjutkan dengan pengujian sistem, yaitu mengukur keberhasilan sistem apakah sudah sesuai dengan tujuan dan kebutuhan pengguna.[10].

Berikut beberapa gambar tentang bibit kelapa sawit :
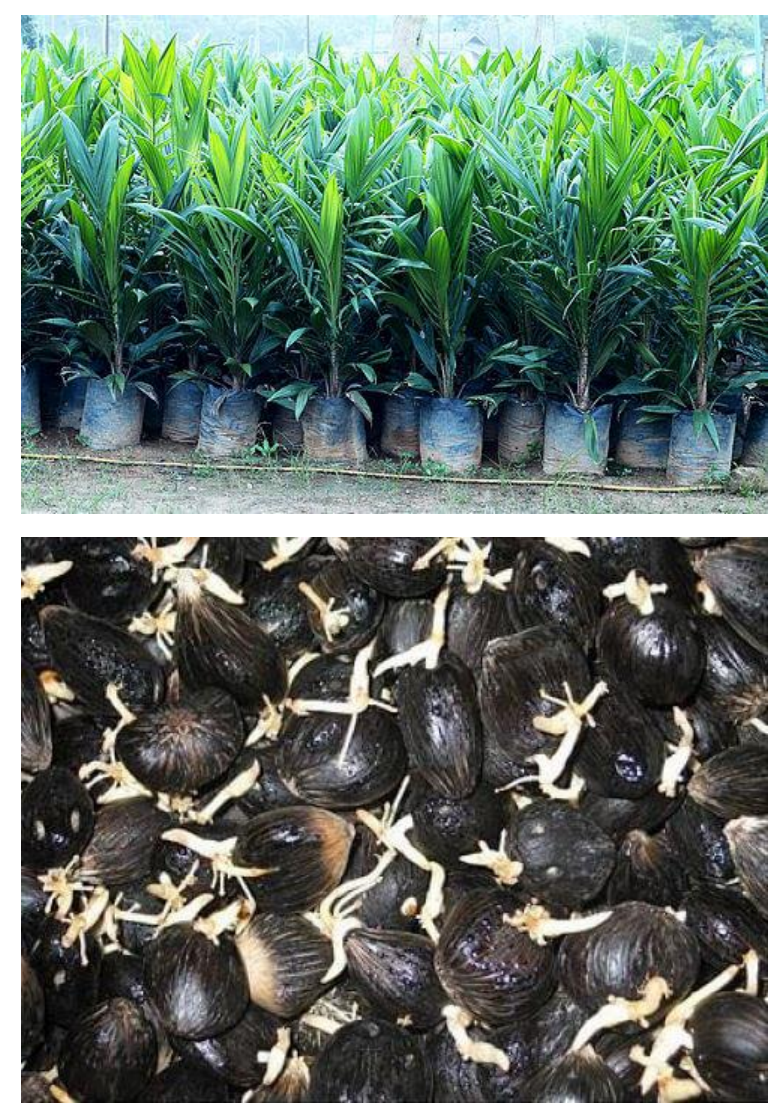

Gambar 2. Bibit Unggul Kelapa sawit

\section{HASIL DAN PEMBAHASAN}

\subsection{Analisis}

Identifikasi user merupakan bagian dari usability yang dilakukan untuk memahami karakteristik petani sebagai pengguna sistem. 
Mengatakan jenis kelamin memiliki kecenderungan dalam pemilihan warna dalam interface[11].

\subsection{Identifikasi Sumber Daya}

Identifikasi sumber daya yang dibentuk oleh tim KM yang terdiri dari : petani dan pakar kelapa sawit, Dinas Perkebunan Provinsi Papua, Sistem analis dan programmer mempunyai tugas dan tanggung jawab masing-masing.

\subsection{Identifikasi Sumber Pengetahuan}

Identifikasi sumber pengetahuan dilakukan dengan wawancara terhadap tim KM yang dibentuk oleh Dinas Perkebunan Provinsi Papua. Maka Identifikasi sumber pengetahuan juga merupakan prosedur untuk pengkodifikasian pengetahuan yang sesuai yaitu meggunakan knowledge map yang merupakan sebuah representasi visual dari suatu pengetahuan. Knowledge map menjabarkan kejadian yang saling terhubung antara satu kejadian dengan yang lain dalam suatu rangkaian proses.

\subsection{Perancangan}

Perancangan dilakukan dengan beberapa tahap yaitu perancangan sistem dan perancangan basis data. Perancangan sistem berupa alat atau pengetahuan yang telah ditangkap kemudian diubah ke dalam pengetahuan explicit yang kemudian akan digunakan sebagai bahan untuk membangun dari KMS. Pada tahap ini, akan dibuat Data Flow Diagram yang merupakan representasi visual dari KMS yang akan dibangun. Perancangan basis data menggunakan ERD (Entity Relationship Diagram) yang menggambarkan relasi data dalam basis data. Gambar 3 merupakan DFD KMS Bibit Sawit dan Gambar 4 merupakan ERD dari KMS Bibit Sawitnyang akan dibangun.

\subsection{Verifikasi dan Validasi KMS}

Verifikasi dan validasi KMS dapat dilakukan untuk mengetahui apakah data-data yang terdapat pada proses verifikasi dan validasi sesuai dengan proses pada perancangan. Deskripsi uji yang digunakan meliputi pengetahuan yang dihasilkan sudah mencakup semua pengetahuan mengenai bibit sawit, terdapat jurnal yang mewakili tentang sawit, terdapat buku yang mewakili tentang sawit, terdapat petunjuk teknis tentang bibit sawit dengan pengujian tersedia secara baik.

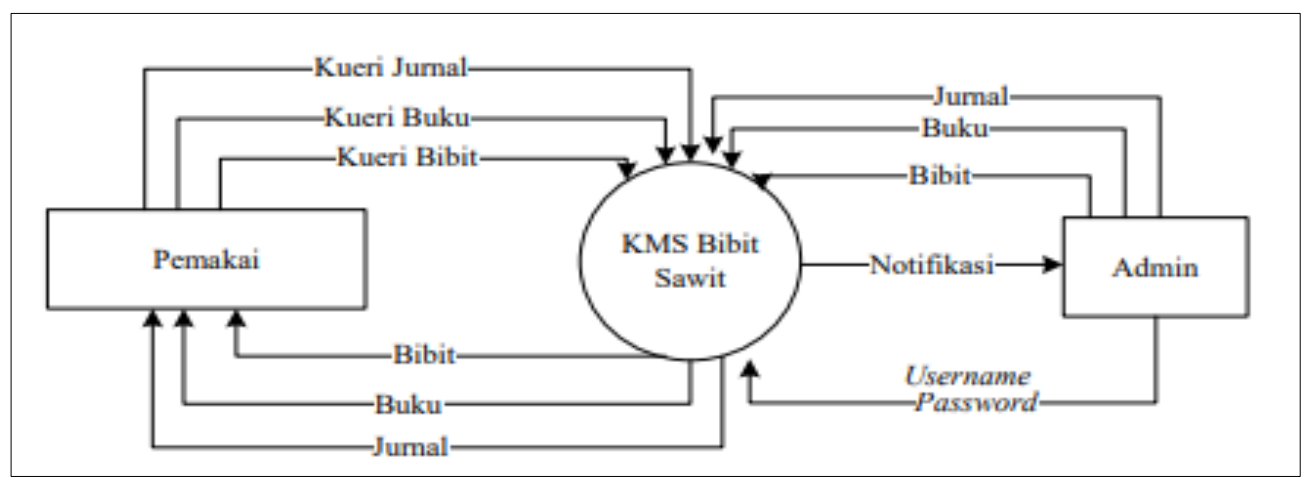

Gambar 3. DFD KMS Bibit Sawit 


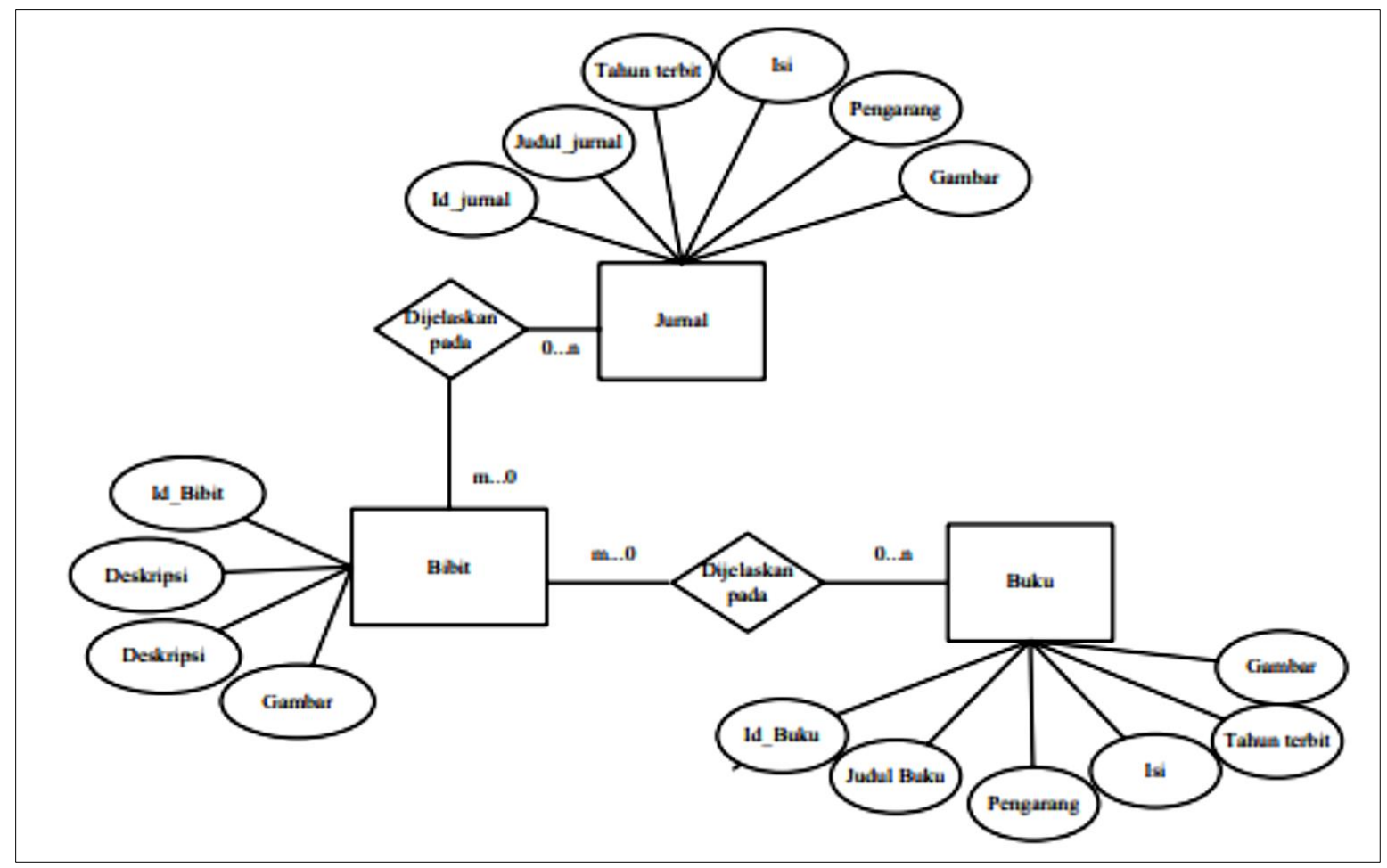

\section{Gambar 4. Entity relationship diagram sistem}

\subsection{Verifikasi dan Validasi KMS}

Verifikasi dan validasi KMS dapat dilakukan untuk mengetahui apakah data-data yang terdapat pada proses verifikasi dan validasi sesuai dengan proses pada perancangan. Deskripsi uji yang digunakan meliputi pengetahuan yang dihasilkan sudah mencakup semua pengetahuan mengenai bibit sawit, terdapat jurnal yang mewakili tentang sawit, terdapat buku yang mewakili tentang sawit, terdapat petunjuk teknis tentang bibit sawit dengan pengujian tersedia secara baik.

\subsection{Implementasi KM}

Hasil dari implementasi KM sistem berupa aplikasi Android. Halaman menu utama pada aplikasi ini hanya diletakkan lima icon yaitu profil, dokumen, search, bibit dan wawancara. Salah satu kendala yang dihadapi oleh para pengguna smartphone adalah antarmuka kecil saat mengakses halaman di internet [12]. Oleh karena itu, pada halaman menu utama diletakkan sedikit iconnya. Menu search merupakan menu pencarian yang dapat digunakan pemakai untuk pencarian informasi bibit kelapa sawit. Menu wawancara dibagi menjadi dua yaitu konsultasi dan wawancara. Adapun hasil penelitian yang diperoleh seperti pada gambar 5 .

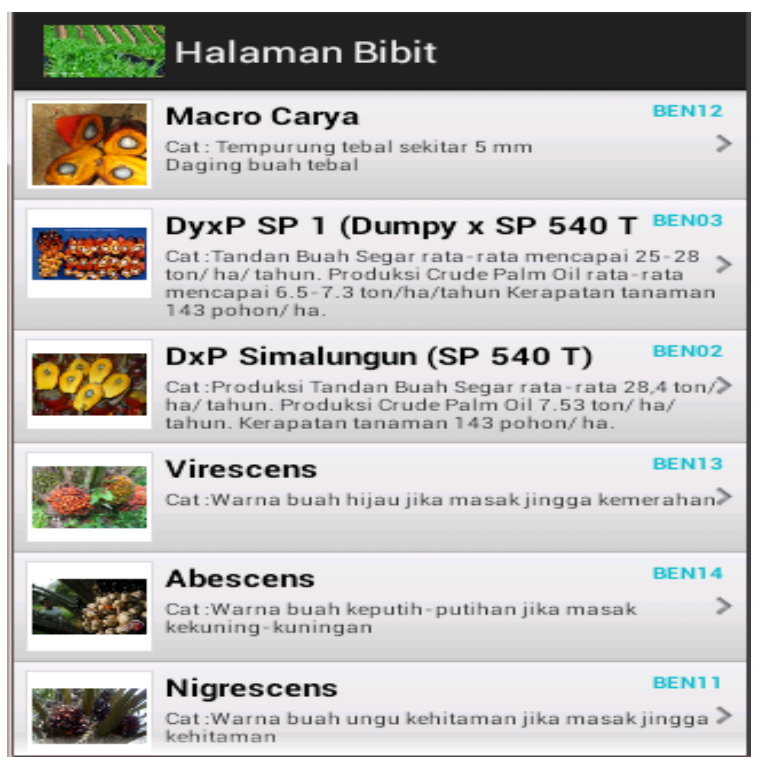

Gambar 5. Halaman Bibit Sawit 


\section{KESIMPULAN}

Sistem pengelolaan pengetahuan bibit sawit ini berbasis Android telah dikembangkan dengan metode KMSLC dengan pendekatan Usability Engineering. Dengan adanya sistem berbasis pengetahuan ini pengguna dapat melihat dan mengunduh informasi melalui smartphone Android sehingga aplikasi KMS ini berguna bagi pengguna. Hasil dari penelitian ini berupa sistem manajemen pengetahuan bibit sawit yang mana sumber data yang digunakan pun meliputi dokumen buku, jurnal terutama yang berasal dari pusat penelitian kelapa sawit serta menyediakan konsultasi dengan pakar sawit. Error rate pada aplikasi ini sangat rendah dan sedikit. Skor dari setiap kategori berada diatas rata-rata artinya usability pada sistem ini sudah baik.

\section{UCAPAN TERIMA KASIH}

Terima kasih kepada Kemenristekdikti yang mendanai penelitian ini sebesar dua puluh juta.

\section{DAFTAR PUSTAKA}

[1] Fauzi Y, Widyastuti YE, Satyawibawa I, Hartono. Kelapa Sawit Ed Revisi. Bogor: Penebar Swadaya. 2013.

[2] Kurnila R. Pengendalian Mutu Produksi Bibit Kelapa Sawit (Elaeis guineensis Jacquin) Di Pusat Penelitian Kelapa Sawit Marihat, Sumatera Utara. [Skripsi]. Bogor(ID): Institut Pertanian Bogor. 2013.

[3] Suryantini H. Pemanfaatan Informasi Teknologi Pertanian Oleh Penyuluh Pertanian. [Tesis]. Institut Pertanian Bogor 2014.

[4] Fernandez IB, Sabherwal R. Knowledge Management: System and Processes. England: M.E. Sharpe. 2012
[5] Gottschalk P. Stage of Knowledge Management Systems In Police Investigations. Knowledge Based Systems Journal. Vol 19: 381-387. 2014

[6] Connell C, Klein JH, Loebbecke C, Powe1 P. Toward a Knowledge Management Consultation System. Knowledge and Process Management Journal Volume 8 Number 1 pp 48-54. 2013

[7] Sarayreh B, Mardawi A, Dmour. Comparative Study: The Nonaka Model Knowledge Management. International Journal of Engineering ad Advanced Technology (IJEAT). Vol. 12012.

[8] Mayhew DJ. The Usability Engineering Lifecycle. University California. Morgan Kaufhan Publishers. 2014.

[9] Nielsen J, Loranger H. Prioritizing Web Usability. Berkeley: New Riders. 2012.

[10] Awad EM, Ghaziri HM. Knowledge Management. Prentice Hall. 2010.

[11] Levin H, Passig D. Gender Interest Differences With Multimedia Learning Interfaces. Computer in Human Behavior Journal. Vol 15: 173-183. 2011.

[12] Lobo D, Kaskaloglu K, Kim C, Herbert S. 2011. Web usability guidelines for smartphones: a synergic approach. International Journal of Information and Electronic Engineering. 1(1):33-37. 2011. 